\title{
The Effectiveness of Law Number 6 Year 2018 and Law Number 4 Year 1984 in Handling the COVID-19 Pandemic for Inter-Island Travel in Ambon City
}

\author{
Hadibah Z. Wadjo", Juanrico A. S. Titahelu, Denny Latumaerissa, Judy M. Saimima, Patrick Corputty \\ Faculty of Law, University of Pattimura, Jl. Ir. M. Putuhena, Poka, Tlk. Ambon, Kota Ambon, Maluku, Indonesia
}

DOI: $10.36348 /$ sijlcj.2021.v04i02.007

| Received: 24.01.2021 | Accepted: 09.02.2021 | Published: 13.02.2021

*Corresponding author: Hadibah Z. Wadjo

\section{Abstract}

This paper specifically wants to analyze the effectiveness of Law Number 6 Year 2018 and Law Number 4 Year 1984 in Handling the Covid-19 Pandemic for Inter-island Travel Players in Ambon City, and Constraints in the Application of Law Number 6 Year 2018 and Law Number 4 Year 1984 in Handling the Covid-19 Pandemic for Inter-Island Travel in Ambon City. This research uses empirical juridical research. The approach used is a statutory approach, the data sources used are primary data and secondary data, data collection techniques that support and are related to this research are interviews, observation and decision studies which are then analyzed qualitatively. The results showed that the Health Quarantine Law, as well as the Disease Outbreak Law which could be used to criminalize anyone who obstructed the handling of the outbreak were not effective for inter-island travelers in Ambon city, because this has never been implemented, which is very ironic with the reality that the perpetrator these trips often violate the law in the form of not following Health protocols. As for the obstacles in the application of the Health Quarantine Law and the Disease Outbreak Law to be applied to inter-island travelers in Ambon city, namely the Factors of Law, Public Awareness, Lack of Quarantine facilities, and Lack of Government Control.

Keywords: Covid-19, inter-island travel, pandemic handling.

Copyright (C) 2021 The Author(s): This is an open-access article distributed under the terms of the Creative Commons Attribution 4.0 International License (CC BY-NC 4.0) which permits unrestricted use, distribution, and reproduction in any medium for non-commercial use provided the original author and source are credited.

\section{INTRODUCTION}

The global community was shocked by the emergence of a new type of corona virus which the World Health Organization (WHO) named severe acute respiratory syndrome corona virus-2 (SARS-CoV-2) and the name of the disease as Corona virus disease 2019 (COVID- 19) [1], which hit almost all countries in the world, including Indonesia. The presence of this infectious and deadly virus is strongly suspected to have first appeared in Wuhan (China) and has claimed many lives and greatly affected human life, not only in terms of health, but also in other sectors such as the economic, social, political, and educational sectors nor law.

In the legal sector, the Indonesian government has responded to this phenomenon by issuing various legal products that aim to break the chain of spreading this virus, in addition to the issuance of the Decree of the Head of the National Disaster Management Agency Number 13 Year 2020 concerning the Extension of the Status of Certain Disaster Emergencies as a Result of Disease Coronavirus in Indonesia, the government has emphasized that the spread of the corona virus is a non- natural disaster in the form of a disease outbreak. In connection with covid-19 which is actually a disease outbreak, from a statutory perspective, at least Indonesia has 2 (two) laws that strictly regulate the specifications for handling outbreaks, namely Law Number 4 Year 1984 concerning Contagious Disease Outbreaks (hereinafter referred to as the Contagious Disease Outbreaks Law) and Law Number 6 Year 2018 concerning Health Quarantine (hereinafter referred to as the Health Quarantine Law).

According to the Contagious Disease Outbreaks Law, Article 1 letter a describes an outbreak of an infectious disease as an outbreak of an infectious disease in a community where the number of sufferers has increased significantly more than the usual situation at a certain time and area and can cause disasters. Article 3 of this Law states that the type of disease is determined by the Minister (in this case the Minister of Health).

Criminal threats are also accommodated in the Contagious Disease Outbreaks Law, especially in Article 14 which can be imposed or applied to anyone 
who obstructs the handling of the epidemic either intentionally or negligently (if deliberately threatened with a maximum sentence of one year and/or a maximum fine of one million and if negligent, a maximum sentence of six months and/or a maximum fine of five hundred thousand rupiah).

Deliberate (dolus) in criminal law must concern the three elements of a criminal act, namely the prohibited act, the result which is the main reason for the prohibition, and that the act violates the law [2]. In the Criminal Code (hereinafter referred to as KUHP) there is not a single article that gives meaning or meaning about intentionality, but according to the explanatory memory (Memorie van Toelichting) what is meant by deliberation is willens and knows (willens en wetens), which means a person who does something on purpose must will (willens) what he does and must know (wetens) what he is doing and its consequences [3].

A person who does an action because of being forced by another person or because of the reflex motion cannot be said that he wants the action. Likewise, a madman does not know and will his actions and the consequences of his actions. Children who are very young in age cannot be expected to know the consequences of their actions but they prefer their actions because a young child always wants to try to do something without realizing or knowing the consequences that can occur from his actions. So willen en weten is an element that must be met by both to convict someone in a deliberate capacity [4].

Negligence (culpa) in criminal law is defined as "not taking preventive measures" or "not being careful" [5]. According to Vos, negligence has 2 (two) elements, namely [6]:

a. The maker can "suspect" the result of his actions;

b. The maker is "less careful" (there is a lack of responsibility in the maker)

To be able to suspect an effect means that there must be a relationship between the mind of the maker and the result that arises because of his actions. In addition, there must also be a birth relationship which is a causal relationship between the actions of the maker and the prohibited consequences. If this causal relationship does not exist then it cannot be accounted for. Even if voorzienbaarheid is occurring, it is not a culpa because in addition, it is also necessary to be inadvertent (onvoorzichtigheid).

A person who has previously been able to suspect that there might be a bad result from his actions, but that action is the only way to get a good result so that he cannot choose any other way. Apart from that he has done his best or with utmost care in order to succeed well, even though bad consequences are likely to occur. For example, a doctor who has to operate on a seriously ill patient. The doctor knew that with the operation there was a high probability that the patient would die, but the operation was the only way to cure the patient. The element of inadvertence (onvoorzechtigheid) was absent from the doctor, even though he knew beforehand that there was a high probability that his patient would die with his operation. So here is not yet a culpa [7].

The next law related to handling disease outbreaks is the Health Quarantine Law. This law can be an option for the government, if in an effort to break the chain of spread of covid-19 by carrying out Health Quarantine. Article 9 of this Law stipulates that Paragraph (1) everyone is obliged to comply with the administration of Health Quarantine, Paragraph (2) Everyone is obliged to participate in the implementation of Health Quarantine. The threat of criminal sanctions in this law is contained in article 93 which reads:

Every person who does not comply with the implementation of Health Quarantine as referred to in Article 9 paragraph (1) and/or obstructs the implementation of Health Quarantine so as to cause a Public Health Emergency will be sentenced to imprisonment of up to 1 (one) year and / or a maximum fine of $\mathrm{Rp} 100,000,000.00$ (one hundred million rupiah).

The Health Quarantine Law, especially in Article 15, substantially regulates:

\section{Article 15}

1. Health Quarantine at Entrance Gates and in the area is carried out through monitoring of diseases and Public Health Risk Factors for Transport Equipment, people, goods and/or the environment, as well as responses to Public Health Emergencies in the form of Health Quarantine measures.

2. Health Quarantine Measures as referred to in paragraph (1) shall be in the form of:

a. Quarantine, Isolation, vaccination or prophylaxis, referral, disinfection and/ or decontamination of people as indicated;

b. Large-Scale Social Restrictions;

c. Disinfection, decontamination, disinsection, and/or deratization of Transport Equipment and Goods; and/or

d. Health, safety, and control of environmental media.

3. Restructuring, safeguarding and controlling environmental media as referred to in paragraph (2) letter $\mathrm{d}$ shall be implemented in accordance with the provisions of laws and regulations;

4. Further provisions regarding Health Quarantine measures as referred to in paragraph (2) shall be regulated in a Ministerial Regulation. 
The Health Quarantine Law especially in Chapter VII regulates the implementation of Health Health in Regions, which in Article 49, substantially reads:

\section{Article 49}

1. In order to mitigate risk factors in areas in a public health emergency, home quarantine, regional quarantine, hospital quarantine, or large-scale social restrictions are carried out by Health Quarantine officials.

2. Home Quarantine, Regional Quarantine, Hospital Quarantine, or Large-Scale Social Restrictions as referred to in paragraph (1) must be based on epidemiological considerations, threat magnitude, effectiveness, resource support, technical operations, economic, social, cultural and security.

The regulation in the Health Quarantine Law, especially in article 15 and article 49 as stated above, shows that there are 5 (five) types of Health Quarantine, one of which is Large-Scale Social Restrictions (hereinafter referred to as PSBB), which is a policy chosen by the president of the Republic of Indonesia. Jokowi as a preventive effort in breaking the chain of the spread of covid-19 in Indonesia, which is currently being implemented by most regions in Indonesia including Ambon City which has entered into an extension of its implementation. Guidelines for implementing PSBB are regulated in the Minister of Health Regulation Number 9 Year 2020 concerning Guidelines for Large-Scale Social Restrictions in the Context of Accelerating the Handling of Corona Virus Disease 2019 (Covid-19).

In its application, PSBB is not absolutely prohibited to prohibit people from leaving the house, but rather in regulating restrictions on individual interactions. This is as stated in Government Regulation Number 21 Year 2020 concerning Large-Scale Social Restrictions in the Context of Accelerating the Handling of Corona Virus Disease 2019 (covid-19) (hereinafter referred to as Government Regulation No. 21 Year 2020) which in this Government Regulation states that existing activity restrictions still consider the needs of education, work productivity, and community worship. At work, it is possible for some to do Work from Home and others to continue working as usual on condition that they are physically restricted or NonWork from Home.

The implications of Government Regulation No. 21 Year 2020 are deeply felt in community activities, especially in carrying out crossprovince/regency/city travel activities, which is confirmed in the regulation in the Circular of the Task Force for the Acceleration of Handling Covid-19 Number 7 Year 2020 concerning the Criteria and Conditions for Corona Travel Virus Disease 2019 (Covid-19), in which there are criteria and requirements that must be met when a person travels both domestic and abroad, where the problem in this writing is focused on domestic travelers, the arrangements are as follows:

\section{Criteria and Requirements}

Domestic travel requirements: a. Every individual who travels in a private vehicle is responsible for his/her health, and is subject to and obeying the applicable terms and conditions; b. Every individual traveling by land, rail, sea and air public transportation must meet the following requirements: 1) Show personal identity (KTP or other valid identification); 2) Showing a PCR test certificate with a negative result that is valid for 7 days or a Rapid-Test test certificate with a non-reactive result that is valid for 3 days at the time of departure; 3) Showing a symptom-free certificate such as influenza (influenza-like illness) issued by the Hospital Doctor/Puskesmas for areas that do not have PCR and / or Rapid-Test facilities; c. Domestic person travel requirements are exempted for commuter trips and person trips within agglomeration areas.

Interestingly, in the midst of the government's efforts to handle the spread of the Covid-19 chain, including by applying the criteria and conditions that must be met by domestic (provincial/city/district) travelers, however, in its implementation there have been many actions that are suspected to be criminal acts related to Covid-19 handlers, for example a logistic truck driver (traveler) who made a trip without being equipped with a PCR test certificate with a negative result that is valid for 7 days or a Rapid-Test test certificate with valid non-reactive results 3 days upon departure.

\section{RESEARCH METHOD}

This research uses empirical juridical research. The approach used is a statutory approach, the data sources used are primary data and secondary data [8], data collection techniques that support and are related to this research are interviews, observation and decision studies which are then analyzed qualitatively.

\section{RESULTS AND DISCUSSION \\ The Effectiveness of Laws in Handling the Covid-19 Pandemic for Inter-island Travel in Ambon City}

The corona virus case appeared and attacked humans for the first time in Wuhan province, China. Early appearance is thought to be pneumonia, with symptoms similar to flu in general. These symptoms include coughing, fever, fatigue, shortness of breath and no appetite. But unlike influenza, the corona virus can develop rapidly, resulting in more severe infections and organ failure. 
This emergency occurs mainly in patients with previous health problems. Due to the very fast transmission of the corona virus, the World Health Organization (WHO) declared the corona virus a pandemic on March 11, 2020. The status of a pandemic or global epidemic indicates that the spread of Covid-19 is progressing so fast that almost no country in the world can ensure that it is spared of the corona virus [9].

In deciding the spread of this deadly virus, it is necessary to have the seriousness of all countries in overcoming it. No exception in Indonesia, including handling it in Ambon City. Ambon is a city in Eastern Indonesia, which is the capital of Maluku Province. The city known as "City of Music" can be said to be the economic center in Maluku, which is marked by the large number of people from other provinces/cities/districts who are "trying their luck" here.

As a result of the Covid-19 pandemic, it has an impact on the travel activities of people who come and want to leave this city, this is an implication of establishing anticipatory policies to overcome the impact of Covid-19, which on March 31, 2020, President Jokowi held a Conference The press, with the aim of announcing to the public about the policies it has chosen to address Covid-19 as a global pandemic currently being faced by the Indonesian people. At the press conference, President Jokowi issued a statement that the Large-Scale Social Restrictions policy was the policy chosen in response to Health Emergencies.

The Health Quarantine Law is the legal basis for this anticipatory policy. The meaning of Large-Scale Social Restrictions is the limitation of certain activities of residents in an area suspected of being infected with Corona Virus Disease 2019 in such a way as to prevent the possible spread of Corona Virus Disease 2019. At the press conference, President Jokowi also emphasized that Regional Governments should not apply their own policies in their regions that are not in accordance with Central Government protocols. Local governments and the private sector are obliged to comply with the PSBB determined by the central government, if they do not comply with or obstruct the implementation of the PSBB, they can be charged with criminal sanctions [10].

This is as the author has explained in the previous chapter that criminal sanctions for not obeying or obstructing the implementation of the PSBB are contained in article 93 of the Quarantine Law with a maximum imprisonment of 1 (one) year and/or a maximum fine of Rp. 100,000,000.00 (one hundred million rupiah).
Prior to the implementation of the PSBB in Ambon City, the local government since January 2020 has started working to prevent the spread of covid-19 but in the form of a task force with a special task to handle health clusters under the health office, which the task force team was formed starting from an allegation students studying in Bali from the Tanimbar Islands Regency (KKT) traveled to Singapore and Malaysia and returned to KKT suspected of being infected with Covid-19.

In its development on March 22, 2020, the first case of covid-19 in Ambon, namely a construction worker from Bekasi who was infected with Covid-19, a task force was formed, this was a breakdown of central government policy, which at that time all transportation mode activities, human movement is still normal, but then the task force made arrangements related to restrictions on travel activities for travelers in order to break the chain of covid-19 [11].

At that time, there was no room for selfquarantine of travelers as a whole, while every day approximately 1000 (one thousand) people travel to Ambon, either through Pattimura airport, through ports in the surrounding city districts or by land (district which is still on the same land as Ambon City, namely Central Maluku).

Then the next development, namely travelers from the province/district/city to enter Ambon provided a quarantine place by the task force. There are 2 (two) types of Health quarantine that are enforced, namely [12]:

1. Outsiders travel to Ambon for a specific destination and during a certain period of time a quarantine place is provided, namely training both belonging to the provincial government and belonging to the ministries in Ambon, for example, such as the Religious Training in Waiheru, provincial agricultural training, haj dormitories, LPMP, BPSDM and BP3 belong to the Ministry of Fisheries. All their needs are prepared including family kids and eating snacks. For example, when travelers from outside Ambon come to Ambon, the task force records at the airport, Maluku people are self-quarantined, but those from outside Maluku are quarantined at the training centers as explained before Kalua from outside Ambon made an official trip here during 3 days then it will be quarantined 3 days after that it will be sent home

2. City/regency travel actors are self-quarantined for 14 days and can only travel (confirmed to be sterile from covid-19) and given a covid-19 free letter by the task force to accelerate handling of the spread of covid-19 which explains that the traveler has been quarantined 
Ambon City currently has no centralized quarantine because the confirmed cases of Covid-19 have increased, while hospital facilities are limited, the number of medical is limited so that the training, which was a quarantine place, has been converted into emergency hospitals (isolation places) to serve patients with mild and moderate status. The Covid-19 referral hospital in Ambon city, namely [13]:
1. RSUD Haulusi;
2. RST dr. Latumeten;
3. Bhayangkara Police Hospital;
4. RSUP Leimena;
5. RSUD Tulehu;
6. Siloam International Hospital,

As explained above, travelers who enter and leave Ambon can go by air, sea or land. This research focuses on travelers who use sea routes, especially ferries who are suspected of violating health protocols, in this case the traveler in question is a logistic truck driver who intends to travel between islands, at Galala, Waai and Liang Ferry Ports.

Based on the results of the author's research by interviewing Jems Gazperz [14], it was found that the Health Protocol applied to travelers who use shipping services at the Galala Port is adjusted to the regulations set by the government, in this case the service user provides a place to wash hands, the traveler must wear a mask and keep a distance between one traveler and another. Especially in implementing health protocols, in this case, keep your distance, it can be realized if the conditions of the passengers are quiet, but if the conditions of the passengers are crowded then this cannot be done, because people want to quickly get tickets, the health protocol to keep the distance will not be done/ignored without thinking the risk of contracting covid-19, this causes passengers to often jostle when passenger conditions are crowded.

This is also a result of restrictions on passengers who will use crossing services. Administrative requirements that must be fulfilled by travelers who use crossing services are required to have a test report, then be verified by the cluster team, in this case the health office, if fulfilled then a yellow card will be given to get a ticket. For passengers who do not have a yellow card, they will not be served.

At each shipping port, there is a task force team to oversee the use of health protocols for travelers as well as to provide socialization regarding health protocols to be used by travelers, however the lack of public awareness greatly affects this implementation (there are still many travelers who ignore it). There have never been any sanctions, either administrative sanctions or criminal sanctions, for travelers who ignore health protocols, all of which are still limited to providing health protocol socialization [15].
Furthermore, according to Jems, the implementation of PSBB as one of the forms that can be carried out in overcoming the spread of infectious diseases as mandated in the Health Quarantine Law, is not in line with expectations, because the community still ignores the Health protocol. Health protocol in motorized crossing (KMP) is realized by limiting the capacity of travelers where the number of travelers using ferry services is reduced by $1 / 2$ (half) of the existing capacity. For example, the passenger capacity, which was initially 320 people before Covid-19, was reduced to 160 people after Covid-19.

There is no special team/team tasked with overseeing enforcement of the Health protocol on board, only facilities are provided to support this, because not everyone including the cluster team can be on board, this is related to the Shipping Law. Initially, logistic truck drivers were required to use a test report, but later they were not again, and replaced by a gradual inspection by showing a able-bodied letter. Every crew member of the ship (ABK) in the KMP routinely undergoes a quick test, if there are crew members who are reactive they must be replaced with crew members from other KMP. The enforcement of the Health protocol at Tulehu, Waai and Liang Ferry Ports is also more or less the same as that of Galala Ferry Ports [16]. Based on this explanation, it can be seen that the Health Quarantine Law, as well as the Disease Outbreak Law which can be used to convict anyone who obstructs the handling of the outbreak are not effective for interisland travelers in Ambon city, because this has never been implemented, which is very ironic with the existing reality. That the said traveler often violates the law in the form of not following the Health protocol.

\section{Constraints in the Application of the Law}

The effectiveness of a law product to be enforced in a society must be supported by good law enforcement by law enforcers, besides that the community also takes an important role in its enforcement which is manifested in the form of obedience. Meanwhile, according to Soerjono Soekanto [17], the factors that influence society and law enforcers in the law enforcement process are:

1. Law Factors, which in a material sense, means written regulations that are generally accepted and made by the central and regional authorities. Laws that will have a positive impact on society must comply with several statutory principles, including not retroactive; laws made by a higher authority have a higher position; Laws that are specific in nature override laws that are general in nature; the law that was in effect later, annulled the law that was in effect earlier. Ignoring these principles can cause interference with law enforcement. In addition, the absence of implementing regulations and the unclear meaning of the words in the law can also interfere with law enforcement. 
Vagueness of words in statutory regulations can occur because of the use of words whose meaning can be broadly interpreted;

2. Law enforcement factors, which include parties directly or indirectly involved in law enforcement. There are several obstacles that are usually encountered by law enforcers in order to enforce the law, namely lack of adaptability, lack of aspirations, lack of futuristic thinking, materialism, and lack of innovation. These obstacles can be overcome by getting used to being open, flexible, sensitive, knowledgeable, systematic, confident, optimistic, calculating, not technologically illiterate, respecting oneself and others;

3. Facilities that support law enforcement, such as qualified and skilled human resources, adequate equipment and sufficient finance;

4. Community factors, namely the environment in which the law applies or is applied. Public acceptance of the law is believed to be the key to peace. Usually Indonesian people define law and even identify it with law enforcers;

5. Cultural factors, namely as a result of work, creativity, and taste based on human initiative in social life.

The five factors are interrelated with one another because they are the essence of law enforcement and are also a measure of the effectiveness of law enforcement [18]. The obstacles in the application of the Health Quarantine Law and the Disease Outbreak Law to be applied to inter-island travelers in Ambon City, namely:

1. Legal factors. The implementation of both Law Number 4 Year 1984 and Law Number 6 Year 2018 in Indonesia has not been effective so far. This is the background for the issuance of Government Regulation Number 21 Year 2020 concerning Large-Scale Social Restrictions in the Context of Accelerating the Handling of Corona Virus Disease 2019. In its development, this Government Regulation has drawn various criticisms. This is due to the various problems that exist in the provisions of the Government Regulation, one of which is the title of this Government Regulation, namely Large-Scale Social Restrictions in the Context of Accelerating Handling of Covid-19. The title used indicates that the scope to be regulated by this PP is very narrow, namely PSBB. Even more specifically, it is only about PSBB in the context of handling Covid-19. So it is clear that the legal politics of controlling infectious disease outbreaks in Indonesia as a whole is still ineffective. This has clearly harmed society at large and resulted in social injustice [19].

2. Community Awareness. Inter-island travel actors in Ambon City, who in fact are people, often ignore Health protocols, this is also influenced by community pessimism regarding the absence of Covid-19.

3. Lack of quarantine facilities. Travel actors from Maluku and Ambon City who return to Ambon will be quarantined independently, but this selfquarantine also has weaknesses, because there is no control from the authorities over the implementation of self-quarantine, there is no guarantee that the implementation of selfquarantine is correct really done according to the Health protocol.

4. Lack of government control. One obstacle to the implementation of the Health Quarantine Law and the Contagious Disease Outbreaks Law in the implementation of the Health protocol for travelers at Liang Harbor is the lack of monitoring from the Central Maluku government. Indeed, there is a post for medical personnel there, but when the medical team from the Puskesmas Waai was suspected of being infected with Covid-19, all medical personnel were withdrawn and after that there were no more medical personnel who were seconded there but the medical personnel at the Port remained intense there to do this supervision. However, the supervision is less strict [20].

\section{CONCLUSION}

The Health Quarantine Law, as well as the Disease Outbreak Law which could be used to criminalize anyone who obstructed the handling of the outbreak were not effective for inter-island travelers in Ambon city, because this has never been implemented, which is very ironic with the reality that the perpetrator these trips often violate the law in the form of not following Health protocols. As for the obstacles in the application of the Health Quarantine Law and the Disease Outbreak Law to be applied to inter-island travelers in Ambon City, namely the Factors of Law, Public Awareness, Lack of Quarantine facilities, and Lack of Government Control. Therefore, there is a need for comprehensive implementing regulations in the form of government regulations from the Health Quarantine Law and the Infectious Disease Outbreak Act as guidelines for law enforcers so that the treatment of the Covid-19 outbreak is more effective in reducing the number of spread of Covid-19 by implementing criminal sanctions for those who violate or Obstruct efforts to handle covid-19, not only limited to the implementation of the PSBB, because administrative sanctions for violating the PSBB period are not effective. On the other hand, our awareness is to obey and obey and carry out health protocols. Community pessimism regarding the absence of covid-19 must be eliminated because covid-19 exists, covid-19 is real, this is a global problem not a problem in Ambon city alone. Quarantine facilities must also be centralized, not done independently. Government control must always be in place for inter-island travelers in Ambon City. 


\section{REFERENCES}

1. Yuliana, Y. (2020). Corona virus diseases (Covid19): Sebuah tinjauan literatur. Wellness And Healthy Magazine, 2(1), 187-192.

2. Wirjono, P. Asas-Asas Hukum Pidana di Indonesia, PT. Eresco, Bandung, p. 61.

3. Sofjan, S. (1990). Hukum Pidana I, CV. Armico, Bandung, p. 195.

4. Ibid., p. 196

5. Ibid., p. 217

6. Ibid.

7. Ibid.

8. Kadarudin. (2021). Penelitian di Bidang Ilmu Hukum (Sebuah Pemahaman Awal), Semarang: Formaci Press, 223.

9. Mona, N. (2020). Konsep Isolasi Dalam Jaringan Sosial Untuk Meminimalisasi Efek Contagious (Kasus Penyebaran Virus Corona Di Indonesia). Jurnal Sosial Humaniora Terapan, 2(2).

10. Ristyawati, A. (2020). Efektifitas Kebijakan Pembatasan Sosial Berskala Besar Dalam Masa Pandemi Corona Virus 2019 Oleh Pemerintah Sesuai Amanat UUD NRI Tahun 1945. Administrative Law \& Governance Journal, 3(2), 240-249.
11. Interview with Hendrik Far-Far, secretary of the Maluku Province Covid-19 Task Force, on December 7, 2020

12. Ibid.

13. Ibid.

14. Interview with Jems Gazpers, Galala Ferry Port Supervisor, on December 4, 2020.

15. Ibid.

16. Ibid.

17. Luthvi Febryka Nola, Upaya Perlindungan Hukum Secara Terpadu Bagi Tenaga Kerja Indonesia (TKI), Jurnal Negara Hukum, Membangun Hukum yang Berkeadilan dan Kesejahteraan, Vol. 7, No. 1, 2016, p. 39

18. Ria, A. N., \& Agung, B. P. (2017). Efektivitas Pelaksanaan Undang-Undang Nomor 2 Tahun 1960 tentang Perjanjian Bagi Hasil Tanah Pertanian (Tanah Kering) di Desa Bringin, Kecamatan Baya, Kabupaten Purwarjejo. Diponegoro Law Jurnal, $6(2), 4$.

19. Yusriando, Y. (2019). Reformasi Politik Hukum Penanggulangan Wabah Penyakit Berbasis Keadilan Pancasila. Ilmu Hukum Prima (IHP), 2(1),4-5.

20. Interview with Jems Gazpers, Galala Ferry Port Supervisor, on December 4, 2020. 